\title{
Once Daily
}

National Cancer Institute

\section{Source}

National Cancer Institute. Once Daily. NCI Thesaurus. Code C125004.

Scheduled or occurring at a frequency of once per day. 